\title{
GENDER MAINSTREAMING POLICY IN ISLAMIC EDUCATION IN INDONESIA: STUDENTS' PERCEPTIONS ON GENDER ROLES IN ISLAMIC PRIMARY SCHOOL
}

\author{
By: Siti Azisah*
}

\begin{abstract}
The Indonesian government has made a strong commitment to eliminate gender discrimination. To achieve greater gender equality and equity, President Abdurrahman Wahid issued the Presidential Instruction Number 9 Year 2000 to promote gender mainstreaming with the objective of achieving gender equality and equity in all sectors of life. This paper investigates gender perspectives of the students in three Islamic Primary schools: one state school and two private schools in South Sulawesi, Indonesia. The data were gathered by using a number of techniques: group interviews, student drawings, listing famous people and selecting favorite person from their lists of famous people. Three main points emerged from the study: 1) the majority of students had gender-neutral views on sports/games, employment and a range of other social activities; 2) persistent gender stereotyping of some roles by students; and 3) the students from the three schools had divergent views on gender roles and gender identities.
\end{abstract}

KEYWORDS: Gender mainstreaming, equality, inequality, stereotyped, neutral

THE CONCEPT of gender mainstreaming was originated from the Fourth United Nations Conference on Women in Beijing 1995. Gender mainstreaming is defined as an approach employed for integrating gender considerations into planning, formulation, implementation, monitoring, and evaluation of policies and program of development (Instruction of the President of the Republic of Indonesia No. 9, 2000). It was given official support in Indonesia when the government identified gender equality and gender justice as one of Indonesia's national development objectives in its Broad Outline of State Policy (GBHN) 1999,1 in Indonesian National

${ }^{*}$ The Author is a PhD candidate from Victoria University, Melbourne Australia. She got her Master of Educational Studies from Flinders University of South Australia in 1996 and she is a lecturer in the Faculty of Education and Teaching of Alauddin State Islamic University. 
Development Programs (PROPENAS) 2000-2004 as well as in the Presidential Instruction No. 9/2000 on Gender Mainstreaming in National Development. ${ }^{2}$ The instruction on gender mainstreaming requires all government department including National Education and Religious Affairs and other government institutions to apply gender perspectives to the planning, formulation, implementation, monitoring, and evaluation of national development policies and programs in accordance with their responsibilities, function and authority. ${ }^{3}$

The Department of National Education, which had the responsibility to mainstream gender considerations in education, has shown its commitment to that policy by conducting a number of gender mainstreaming activities that started in 2002.4

Involving students as a part of the study gender mainstreaming policy in education was essential. That is because they are not only the targets of the policy but they are also the subjects of the policy. Lynette Parker (1997) in her theory of gender subjectivity stated "individuals through their gendered subjectivities, and especially through their experience in relations with others, constitute their gendered being" ${ }^{5}$ She further explained that "gender is always enmeshed in other dimensions of existence: boys and girls, they are also children and not adults; they come from higher or lower status of families; they are clever or stupid, rich or poor" ${ }^{6}$ She discovered that in Indonesia (Bali) the structure of social relations were notably figured by reflections of place, class origins, age and social status. The Bugis society also had a similar structure of social relations. Susan Millar (1983) discovered that the gender relations of Bugis society completely depended on the hierarchical "social location". 7

This paper is a part of my Ph.D research on gender mainstreaming policy in Islamic education in Indonesia. In this paper, the researcher examine the students' views on gender roles by analysing: the students' responses to question about gender role depiction in textbook pictures shown to them, the students' own drawings of men or women performing a role of their choice, the students' lists on famous people, the students' selection of a favourite person from their list, and the students' occupational aspiration. Three main points emerged from the study. Firstly, the majority of students had gender-neutral or gender non-stereotyped views on sports and games, professions and a range of other social activities. Secondly, there was some persistent gender stereotyping of some roles by students. Thirdly, the students from the three schools had divergent views on gender roles. 


\section{METHOD OF THE STUDY}

This study employed a case study approach. 8 This approach is effective for exploring some specific issues concerning the gender perspectives of one society. The three schools selected were not necessarily represen-tative of the Islamic primary schools in Indonesia or South Sulawesi. In this study the case study approach was employed "to limit generalisation" ${ }^{\prime \prime}$ and to demonstrate the complexity of social life. ${ }^{10}$

The three Islamic Primary Schools in this study were MIN (Madrasah Ibtidayyah Negeri) a State Islamic Primary School located in a village, MIA (Madrasah Ibtidaiyyah Assadiyah) a Private Islamic primary school located in a provincial town, and SDM (Sekolah Dasar Muhammadiyah) a Private Islamic Primary School located in the City of Makassar. The three schools were in different districts of South Sulawesi. The study of the students' perceptions of gender roles involved only the grade six students, the oldest children in these primary schools. the researcher assumed that they were more fluent in expressing their ideas than the students in the lower grades.

Data were collected through a variety of research technique as 'giving a voice' to school children does not, of course, only imply the collection of oral data", 11 so the researcher employed a number of research techniques. These are group interviews, ${ }^{12}$ students' drawing, lists of famous people ${ }^{13}$ and selections of students' favourite famous person. The data were analysed qualitatively. Data from the group interview were coded and grouped according to themes. The students' drawings were classified into male and female images and the gender roles of the pictures were identified as gender neutral, gender stereotyped, non-stereotyped or unclear. The lists of famous people and favourite persons were analysed by identifying and analysing the role of the selected people in Indonesian society generally and in terms of gender role depiction, and identifying the most frequently selected people.

In the group interview, the researcher employed a set of pictures. The researcher asked what the pictures were about. Then the researcher asked what they thought about the picture. After that, the researcher enquired what they thought about gender roles in the pictures. The pictures used were taken from school textbooks that illustrated the role of males and females in sport and games, employment and other social activities.

Besides, the researcher asked the students to draw at least one female and male in whatever role they liked. The students were permitted to copy the images from textbooks and the images of the interview tools if they chose. They were also asked to colour their pictures to give clearly indicate 
male and female roles. The students' drawing were then collected and organised in four categories: gender stereotypes, gender non-stereotypes, gender-neutral and unclear. Each category was also divided into male and female.

Furthermore, the researcher asked the students to list famous people both males and females in whatever role they performed, local, national and international. The results were analysed on three level of analysis: comparing the number of males and females and assessing the most often listed famous people in each school, and examining whom the male and female student nominated.

Having asked the students to list their famous people, the researcher asked each student to choose their favourite person from their own lists. The researcher also asked the reason why they nominated that person. The students' favourite people were analysed as follows. Who came to mind of a student when he/she mentioned his/her favourite person? Which gender was predominant? Who were the people selected by the male and the female students? Were they different? What roles did these students' favourite men and women perform? Did they performing stereotyped or non-stereotype or gender-neutral roles in Indonesian society?

Finally, the researcher examined the students' employment aspiration. What future occupation did they dream about? The objective was to find out whether the students' employment aspirations were gendered. The students' aspirations were gathered at the end of the class interviews. The interview participants were asked one by one about their future dreams.

\section{GENDER-NEUTRAL AND NON-STEREOTYPE VIEWS OF GENDER ROLES}

Gender-neutral views of students were revealed mainly from the group interviews and some of the student's drawings. The group interviews of students on gender roles in sports and games, work and domestic activities revealed that students in the three schools (MIN, MIA and SDM) were egalitarian. They considered the majority of sports and games, employment and domestic activities to be gender-neutral even though the majority of pictures shown to them were male predominant and gender stereotyped. The students' views were coincided with the objectives of the gender mainstreaming policy.

The students considered running, cycling gymnastics, badminton, table tennis, and computer game as gender neutral activities. The students considered that these games were for both males and females. For example all students stated that "perempuan dapat juga bermain badminton" [women 
can also play badminton] although the picture shown was of a boy playing badminton (See the Figure 1).

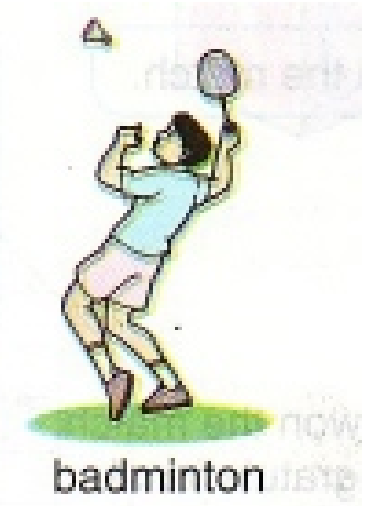

Figure 1: a boy is playing badminton. The students considered a girl could also play badminton.

Gender-neutral views of the students for all the sport and games mentioned above were reasonable as those sports and games were popular for both males and females in Indonesia. Badminton, for example, is a popular sport in Indonesia. Indonesian badminton players are among the best in the world for both male and female players. So it is not surprising, that the students recognized badminton as a gender-neutral game.

Furthermore, students considered the majority of professions were gender neutral. These professions were: school teacher, police, farmer, pilot, manager, judge, specialist doctor, general practitioner doctor, heroes, craftsman, and boy-scout leader. For example, a teacher can be either a female or a male (see the figure 2).
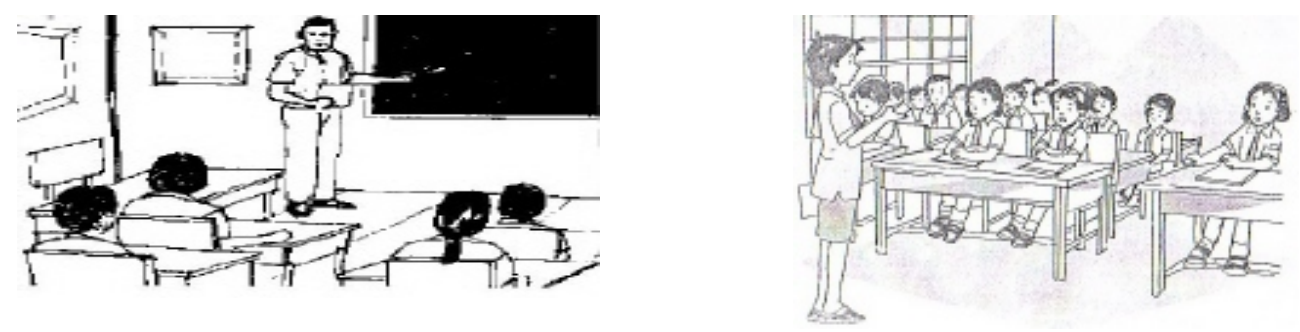

Figure 2: a male teacher a female teacher

Besides, there were also some non-stereotype pictures. Some of the MIN and SDM students depicted a boy making up the bed. There were also students who drew a national heroine and a boy helping his mother prepare a meal. 


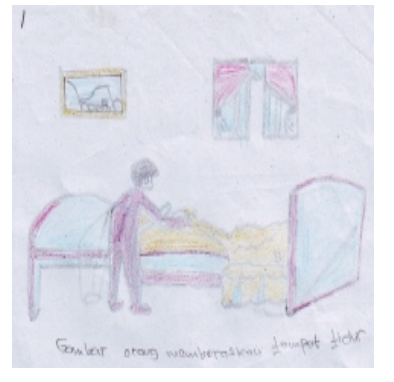

Figure 3: A non-stereotype gender role picture of a boy making up a bed (Picture drawn by a female student of MIN)

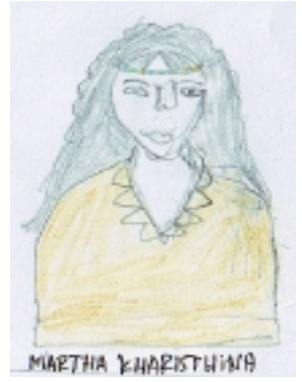

Figure 4: A non-stereotype gender role picture of a heroine (Picture drawn by a male student)

Furthermore, non-gender stereotyped roles were also found in the students' lists of famous people including the former female president (Megawati Sukarnoputri), the national heroines (RA Kartini, Tjut Nya Dien, Kristina Martha Tiyahahu), and the contemporary female government ministers as well as a female sports champion. Megawati was the contemporary female figure most frequently listed and the only current person frequently listed (see further discussion in section D).

\section{GENDER STEREOTYPE VIEWS ON GENDER ROLES}

Gender stereotype was defined by Shaw as "assumptions made about the characteristics of each gender, such as physical appearance, physical abilities, attitudes, interests, or occupation". ${ }^{14}$

The students' views of stereotype gender roles were evident mainly from their drawings, lists of famous people and selections of their favourite person. The students' drawings in three schools were mostly stereotype portrayals of gender roles. The stereotyped male images were of a farmer, a timber worker, a policeman, and a hero. On the other hand, the female stereotype images were a female preparing meals and a female teacher. The three images below were typical of the students' portrayal of gender roles. 


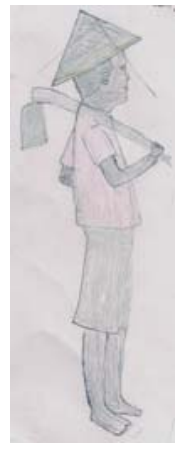

Figure 5: A stereotype gender role picture of a male farmer (Picture drawn by a male student)

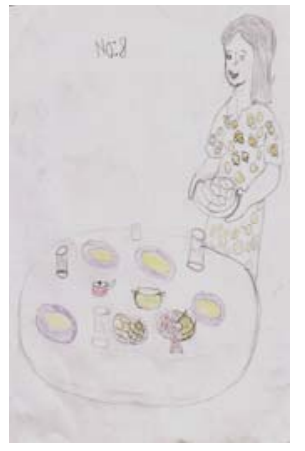

Figure 6: A stereotype gender role picture of a female preparing meal (Picture drawn by a male student)

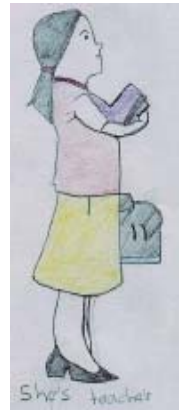

Figure 7: A stereotype gender role picture of a female teacher (Picture drawn by a male student)

Moreover, the students' stereotype views could be found in the selection of famous people. The students in all the schools selected more male famous people than female ones. In addition, the majority of the most frequently listed people were male. The most often listed by students in three schools were Vice President Muhammad Jusuf Kalla, who comes from South Sulawesi, President Susilo Bambang Yudoyono, RA Kartini, a colonial era heroine, and former President BJ Habibie, who like Kalla is from the same province as the students. Three of four most often listed were males and all of them appear in the media frequently.

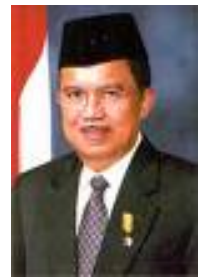

Muhammad Jusuf Kalla (The Vice President)

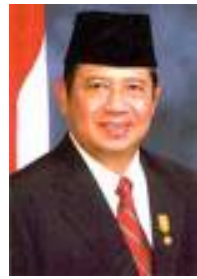

President Susilo Bambang Yudoyono

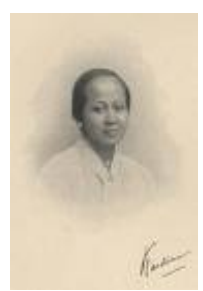

RA Kartini (A national heroine)

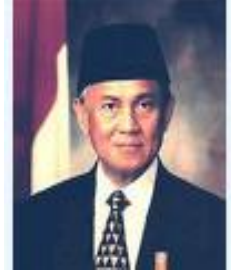

BJ Habibie (The third President)

Figure 8: The most often listed famous people

This indicated that students perception on famous people were male predominant and strongly influenced by media exposure. The female who was most frequently listed was Kartini. The students recognised her not only from textbooks and the media, but her birthday is celebrated every 
year as a national holiday. The popularity of Kartini suggests that the students did not recognise other historical female figures or contemporary female leaders. In fact, many other women have played important roles in educational provision for women, such as Dewi Sartika in West Java, and Maria W. Maramis in North Sulawesi in the early twentieth century. Furthermore, women were involved as warriors in earlier anti-colonial struggles such as Nyai Ageng Serang (1752-1828), Tjoet Nyak Dien (18501908) Tjoet Mutia (1870-1910). ${ }^{15}$ There were also many local female warriors such as Opu Tenrisaju. Not only that, about one fifth of the rulers in the Kingdom of Bone, South Sulawesi since fourteenth century were females and in Wajo, four out six great chiefs were women. ${ }^{16}$ However, none of them were recognised by the students. Indeed, none of them have the same profile as Kartini in textbooks or in the classroom portraiture of national figures. The students' selections reflected Elizabeth Martyn's argument that the ".... Indonesian women's movement has received little attention in scholarship on Indonesian politics and history". ${ }^{17}$ In contemporary Indonesia, women actually have played prominent roles in many aspects of national life, including as the president of the country. The current edition (October 2007) of Globe Asia Magazine published the polling results of the list of Indonesia's 99 most powerful women. The lists included politicians, entrepreneurs, and celebrities, social and social activists. At the top of the list was Megawati Sukarnoputri. ${ }^{18}$ Included in the list of entrepreneurs was Fatima Kalla from South Sulawesi, the youngest sister of the VicePresident. ${ }^{19}$

In addition, the selection of their favourite from their list of famous people also showed the male stereotyped model. Furthermore, the students favoured none of the current female figures. The current figures were all males: Taufik Hidayat, B.J. Habibie, and Susilo Bambang Yudoyono.

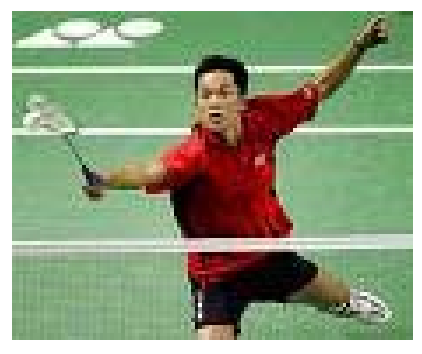

Figure 9: Taufik Hidayat, a badminton star that the students listed frequently and favoured 


\section{THE COMPARISON OF STUDENTS' VIEWS IN THREE SCHOOLS}

In this section, the researcher compare the perceptions of the students from the three Islamic schools in the different socio-cultural settings of rural, semi urban and urban. The first school was the State Islamic School (MIN) located in the village of Bone Regency. In MIN, the students do not have a uniform distinctive from the students in other public schools (SD) all over Indonesia. They wear similar uniforms: white tops and dark red pants. The second school was the private Islamic school (MIA) located in a provincial town of Wajo Regency. The MIA students have distinctive uniforms different from the public school students. The girls wear long sleeved tops and long skirts and the boys wore long pants. Their uniforms followed the Islamic dress code. The last was also a private school (SDM). It was located in Makassar, the capital city of South Sulawesi. The SDM students also wear uniforms that followed the Islamic dress code like the students of MIA. The different uniforms illustrated the difference between the state and the private Islamic primary schools, with the latter adopting Islamic dress code.

Although they were different in appearance, the students in three schools generally shared similar views on gender roles as detailed in the previous discussion of gender neutral/non-stereotype as well as gender stereotype. Yet, there were also markedly different patterns of students' gender perceptions in the three schools. First, different views of students were most evident in the selection of famous people. The students of MIN were the least stereotyped in their choice of the famous, selecting marginally fewer females than males. While, the gap between the male and female nominations of the famous was much greater among the MIA and SDM students: 42 percent and 76 percent respectively. Furthermore, the assessment of who were the most frequently listed by students in each school revealed that students of MIN more often listed famous females than the students of the other two schools. MIN students had three females among their most frequently listed famous people: former President Megawati Sukarnoputri, R.A. Kartini, the colonial-era heroine, and Inul Daratista, a controversial dangdut pop star. While the MIA students had only one female (RA Kartini), but she was in the top position. The SDM students had all males in six of most frequently listed famous people; a female (RA Kartini) was the seventh most often listed.

It was interesting to see that students of MIN listed frequently the highest number of females among other schools. The students' selection of Kartini did not show a big difference from the other two schools. However, 
the number of students who selected Megawati and Inul were far higher in MIN than in MIA and SDM. The role of Megawati and Inul was not the same even though both of them play prominent roles in public. Megawati played a non-stereotype role as a former female president, while Inul played a traditional role of a woman as an entertainer. Yet both of them sparked public debates.
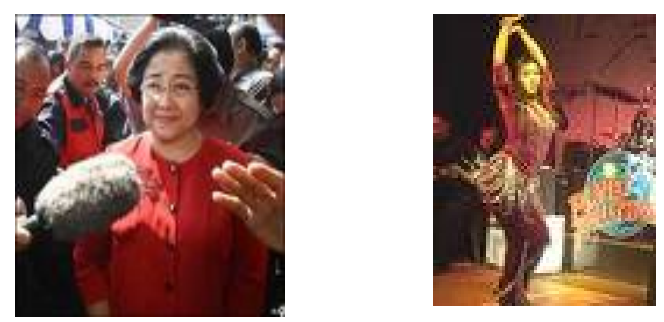

Figure 10: Megawati Sukarnoputri and Inul Daratista both listed most frequently by the students of MIN but not of MIA and SDM

There was a great debate on the role of women as political leaders before the election of Megawati as Indonesia's fifth president. Many politicians used Megawati's gender for political purposes. They put arguments based on a literal translation of a part of a verse of the Qur'an: article 4, verse 34 "The man is a leader of a woman". However, when Megawati became the fifth president they accepted her leadership. ${ }^{20}$ Like Megawati, Inul's role in public life as a dangdut star was also debated, because she did not follow the Islamic code in term of dancing and dress. Inul's dancing was thought by some to be pornographic. Inul, as argued by Mulligan, is "symbolic of women's entry into a public sphere, and challenges the conventional notion of what is appropriate behaviour". ${ }^{21}$ It is worth noting that the dangdut songs performed by Inul were traditionally enjoyed by rural people, such as those in the village where the MIN was located.

The majority of students both in the MIA and SDM seemed aware of debates about Megawati and Inul. They disapproved of the roles played by Megawati and Inul. The students' disapproval, based on their religious values, was reflected in their choices of famous and favourite people. In contrast, the MIN students did not seem to be really concerned with these debates. They accepted and were even attracted by the provocative role of Inul. Their interest in Inul probably reflected their parents' values. Parental values and interests were also reflected in the students' names, particularly those of the female students, which were often those of national entertainers, with high media exposure. This was not the case with the names of the MIA and SDM students. 
Furthermore, the three schools had different patterns in the selection of favourite persons. The selections of the MIN students were female predominant. The selections of the SDM students were the opposite where the majority of the students' favourite person was a male. The selections of MIA's students were more male predominant than the selection of the SDM students.

The students' occupational aspirations revealed different patterns. The MIN students aspired to fewer professions than the students of MIA and SDM. The MIN students both males and females only aspired to be teachers and doctors. The majority of them (males and females) dreamed to be teachers and the rest (one of each male and female) wanted to be doctors. In MIA, the students' occupational aspirations of boys and girls were different. Boys aspired to become teachers, doctors, business persons, and a bank officer, but girls only dreamed of becoming teachers and doctors. Like in the MIA, the boys in SDM also aspired to becoming teachers doctors, pilots, athletes, and soldiers, while the girls only aspired to be teachers and doctors.

\section{CONCLUSION}

The students in the three schools considered the majority of games/ sport, occupations and domestic activities as gender-neutral. the researcher argue that the students' views were mainly influenced by the gender role practices in their community and some non-stereotype images in their textbook and on the classroom walls. The gender stereotype views of the students were more evident in their drawings as well as in the selections of famous and favourite people. These students' stereotyped views appeared to be mainly influenced by the values adopted by students through socialisation at home, at school and through the media.

Although the students in the three schools generally had similar views on gender roles, there were also marked different patterns of perceptions among them. The MIN students were the least stereotyping in their selections of the famous people, whereas the SDM students were the most stereotyping. These differences were likely to be influenced by the ideology and religious values espoused by the school communities. Another different pattern was the students' occupational aspirations. The MIN students had limited occupational aspirations for both girls and boys, while the MIA and SDM students, particularly the boys, aspired to wider range of occupations. However the girls, at these schools, had similarly limited aspirations as the students from the village school. These differences in the students' occupational aspirations reflect the socio-economic differences between the 
schools and the employment opportunities that the students could observe in the community in which they lived and went to school. The gender differences of students' occupational aspirations in MIA and SDM possibly reflect the same religious values evident in the students' selection of famous and favourite people.

The implications of these findings suggest that the schools should use more gender neutral/non-stereotype textbooks, which reflect more accurately the gender role practice in the community in which the students live. The schools also should display more gender-neutral and non-stereotyped images on the classroom walls. The limited aspirations of boys and girls at MIN indicate that the school principals and teachers should encourage male and female students not to limit their aspirations to only two professions. The limited vocational aspirations of the female students at MIA and SDM suggest that the school principals and teachers should widen the horizon of the girls in order that they aspire to various vocations, the same as the boys. The schools should make their students aware that there are many occupations available for both males and females. The schools' teachers should demonstrate that men and women already participate in various occupations.

\section{END NOTES:}

1. Suryadi and Idris, Kesetaraan Gender dalam Bidang Pendidikan, Bandung: Ganesindo, 2004. See also Parawansa, KI, 'Permanent Mission of the Republic of Indonesia to the United Nations ', Women 2000: Gender Equality? Development and Peace for Twenty-First Century, viewed 9 June 2000, <http:/ / www.un.org/ womenwatch/daw/followup.

2. See Ministry of Women's Empowerment Republic of Indonesia, Technical Guidelines for Implementation of Presidential Instruction Number 9 Year 2000 on Gender Mainstreaming in National Development, Jakarta: Ministry of Women's Empowerment Republic of Indonesia,2000. Parawansa, 'Institution Building: An Effort to Improve Indonesian Women's role and status', in $\mathrm{K}$ Robinson \& S. Bessel (eds), Women in Indonesia: Gender, Equity, and Development, Singapore: Institute of Southeast Asian Studies, 2002. Surbakti, $\mathrm{S}$, 'Gender mainstreaming and Sex-disaggregated Data', in K Robinson \& E Sarah (eds), Women in Indonesia: Gender, Equity, and Development (Singapore: Institute of Southeast Asian Studies, 2002). Sadli, M, 'Further Comments on the Economy, with a Gender Perspectives', in K Robinson \& S Bessel (eds), Women in Indonesia: Gender Equity and Development, Singapore: Institute of Southeast Asian Studies, 2002.

3. President of the Republic of Indonesia, Instruction of the President of the Republic of Indonesia on Gender Mainstreaming in the National Development, 9, 2000. 
4. Suryadi, A. \& Idris, E., Kesetaraan Gender dalam Bidang Pendidikan (Bandung: Ganesindo, 2004).

5. Parker, L., 'Engendering School Children in Bali', Journal of the Royal Anthropological Institute, vol. 3, no. 3, 1997, pp. 1.

6. Parker, L., 'Engendering School Children in Bali', Journal of the Royal Anthropological Institute, vol. 3, no. 3, 1997, pp 2.

7. Millar, SB, 'On Interpreting Gender in Bugis Society', American Ethnologist, vol. 10, no. 3, 1983, pp. 477-93.

8. Blaxter, L, Hughes, C. \& Tight, M., How to research, 2nd eds, Buckingham: Open University Press, 2001. See also Reinharz, S \& Davidman, L, Feminist methods in social research (New York: Oxford University Press, 1992) and Yin, RK, Applications of case study research, 2nd edn, Applied social research methods series, (Thousand Oaks: Sage Publications, 2003).

9. Reinharz, S \& Davidman, L., Feminist methods in social research, pp. 167.

10. Blaxter, L., Hughes, C \& Tight, M., How to research

11. Lloyd-Smitt, M. \& Tarr, J., 'Researching Children's Perspectives: A Sociological Dimension', in A Lewis \& G Lindsay (eds), Researching Children's Perspective (Buckingham: Open University Press, 2000), pp. 61.

12. Dockrell, J. Lewis, A. \& Lindsay, G., 'Researching Children's Perspectives: A Psychological Dimension', in A Lewis \& G Lindsay (eds), Researching Children's Perspectives (Buckingham: Open University Press, 2000), pp. 46-58. See also Lewis, A., 'Group child interviews as a research tool', British Educational Research Journal, vol. 18, no. 4, 1992, pp. 413.

13. Sadker, M. \& Sadker, D., Failing at Fairness: How American's School Cheat Girls (New York: Macmillan Publishing Company, 1994).

14. Gooden, AM \& Gooden, M., 'Gender Representation in Notable Children's Pictures Books: 1995-1999', Sex Roles, vol. 45, no. 1/2, 2001, pp. 90.

15. Parawansa, 'Institution Building: An Effort to Improve Indonesian Women's role and status', in K. Robinson \& S. Bessel (eds), Women in Indonesia: Gender, Equity, and Development, . See also Suryochondro, S., 'The Development of Women's Movement in Indonesia', in M Oey-Gardiner \& C Bianpoen (eds), Indonesian Women: The Journey Continues (Canberra: The Australian National University, 2000).

16. Reid, A., 'Female Roles in Pre-colonial Southeast Asia', Modern Asian Studies, vol. 22, no. 3, 1988, pp. 629-45.

17. Martyn, E, The Women's Movement in Post-colonial Indonesia, London: Routledge Curson, 2005, pp. 3.

18. Globe Asia, 'Megawati Sukarnoputri tops Globe Asia's List 99 most powerful women', Globe Asia, October 2007. See also The Jakarta Post, 'Megawati named Indonesia's most powerful woman', The Jakarta post, 2007 and Tribun Timur, 'Fatimah Kalla Kalahkan KD dan Tutut', Tribun Timur, 28 September, 2007.

19. Tribun Timur, 'Fatimah Kalla Kalahkan KD dan Tutut', Tribun Timur, 28 September, 2007.

20. Blackburn, S., Women and State in Modern Indonesia (UK: Cambridge University Press, 2004). See also Sen, K, 'The Mega Factor in Indonesian Politics: A New President or a New Kind of Presidency?' in K. Robinson \& S. Bessel (eds), Women in Indonesia: Gender, Equity and Development (Singapore: Institute of 
Southeast Asian Studies, 2002), Oey-Gardiner, M., 'And the Winner Is ... Indonesian Women in Public Life', in K Robinson \& S Bessell (eds), Women in Indonesia: Gender, equity and development, Platzdasch, B, 'Islamic Reaction to a Female President', in C Manning \& PV Dierman (eds), Indonesia in Transition: Social Aspects of reformasi and Crisis, Singapore: Institute of Southeast Asian Studies, 2000 and Bianpoen, C., Indonesian Women Reclaim their Place Under the Sun, viewed 16/03/2006 2006, http:/ / www.isiswomen.org/wia,1999.

21. Mulligan, D., 'The Discourse of Dandut: Gender and Civil Society', in J. Howell \& D. Mulligan (eds), Gender and Civil Society (Oxon: Routledge, 2005), pp. 1.

\section{BIBLIOGRAPHY:}

Bianpoen, C., Indonesian Women Reclaim their Place Under the Sun, viewed 16/03/2006 2006, http://www.isiswomen.org/wia,1999.

Blackburn, S. Women and State in Modern Indonesia. UK: Cambridge University Press, 2004.

Blaxter, L, Hughes, C. \& Tight, M., How to research, 2nd eds. Buckingham: Open University Press, 2001.

Dockrell, J, Lewis, A. \& Lindsay, G. 'Researching Children's Perspectives: A Psychological Dimension', in A Lewis \& G Lindsay (eds), Researching Children's Perspectives. Buckingham: Open University Press, 2000, pp. 46-58.

Globe Asia, 'Megawati Sukarnoputri tops Globe Asia's List 99 most powerful women', Globe Asia, October 2007.

Gooden, AM \& Gooden, M. 'Gender Representation in Notable Children's Pictures Books: 1995-1999', Sex Roles, vol. 45, no. 1/2, 2001.

Lewis, A., 'Group child interviews as a research tool', British Educational Research Journal, vol. 18, no. 4, 1992.

Lloyd-Smitt, M \& Tarr, J, 'Researching Children's Perspectives: A Sociological Dimension', in A Lewis \& G Lindsay (eds). Researching Children's Perspective. Buckingham: Open University Press, 2000

Martyn, E. The Women's Movement in Post-colonial Indonesia. London: Routledge Curson, 2005.

Millar, SB, 'On Interpreting Gender in Bugis Society', American Ethnologist, vol. 10, no. 3, 1983, pp. 477-93.

Ministry of Women's Empowerment Republic of Indonesia. Technical Guidelines for Implementation of Presidential Instruction Number 9 Year 2000 on Gender Mainstreaming in National Development. Jakarta: Ministry of Women's Empowerment Republic of Indonesia, 2000.

Mulligan, D. 'The Discourse of Dandut: Gender and Civil Society', in J Howell \& D Mulligan (eds), Gender and Civil Society, Oxon: Routledge, 2005.

Oey-Gardiner, M, 'And the Winner Is ... Indonesian Women in Public Life', in K Robinson \& S Bessell (eds). Women in Indonesia: Gender, Equity and Development. Indonesia Assessment Series. Singapore: Institute of Southeast Asian Studies, 2002.

Parawansa, KI, 'Permanent Mission of the Republic of Indonesia to the United Nations ', Women 2000: Gender Equality? Development and Peace for Twenty- 
First Century, viewed 9 June 2000, http://www.un.org/womenwatch/ daw/followup, 2000.

, 'Institution Building: An Effort to Improve Indonesian Women's role and status', in K Robinson \& S Bessel (eds). Women in Indonesia: Gender, Equity, and Development. Singapore: Institute of Southeast Asian Studies, 2002.

Parker, L., 'Engendering School Children in Bali', Journal of the Royal Anthropological Institute, vol. 3, no. 3, 1997.

Platzdasch, B., 'Islamic Reaction to a Female President', in C Manning \& PV Dierman (eds). Indonesia in Transition: Social Aspects of reformasi and Crisis. Singapore: Institute of Southeast Asian Studies, 2000.

President of the Republic of Indonesia, Instruction of the President of the Republic of Indonesia on Gender Mainstreaming in the National Development, 9, 2000.

Reid, A. 'Female Roles in Pre-colonial Southeast Asia', Modern Asian Studies, vol. 22, no. 3, 1988, pp. 629-45.

Reinharz, S. \& Davidman, L., Feminist methods in social research, New York: Oxford University Press, 1992.

Sadker, M \& Sadker, D. Failing at Fairness: How American's School Cheat Girls. New York: Macmillan Publishing Company, 1994.

Sadli, M, 'Further Comments on the Economy, with a Gender Perspectives', in K. Robinson \& S. Bessel (eds). Women in Indonesia: Gender Equity and Development. Singapore: Institute of Southeast Asian Studies, 2002.

Sen, K., 'The Mega Factor in Indonesian Politics: A New President or a New Kind of Presidency?' in K Robinson \& S Bessel (eds). Women in Indonesia: Gender, Equity and Development. Singapore: Institute of Southeast Asian Studies, 2002.

Surbakti, S., 'Gender mainstreaming and Sex-disaggregated Data', in K Robinson \& E Sarah (eds). Women in Indonesia: Gender, Equity, and Development. Singapore: Institute of Southeast Asian Studies, 2002.

Suryadi, A. \& Idris, E. Kesetaraan Gender dalam Bidang Pendidikan. Bandung: Ganesindo, 2004.

Suryochondro, S. 'The Development of Women's Movement in Indonesia', in M Oey-Gardiner \& C Bianpoen (eds), Indonesian Women: The Journey Continues. Canberra: The Australian National University, 2000.

The Jakarta Post, 'Megawati named Indonesia's most powerful woman', The Jakarta post, 2007.

Tribun Timur, 'Fatimah Kalla Kalahkan KD dan Tutut', Tribun Timur, 28 September, 2007.

Yin, RK. Applications of case study research, 2nd edn, Applied social research methods series. Thousand Oaks: Sage Publications, 2003. 